\title{
Move Fast and Break Things
}

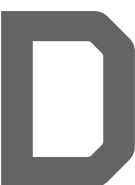

I S R U P T I VE IN N OVATI O N, A term coined by Clayton Christensen, describes a process by which a product or service takes root initially in simple applications at the bottom of a market and then relentlessly moves up market, eventually displacing established competitors. In a highly popular 1995 Harvard Business Review article, "Disruptive Technologies: Catching the Wave," coauthored with J.L. Bower, the authors described how leading companies fail to stay at the top of their industries when technologies or markets change. The running example used in the article is the evolution of the hard-disk-drive industry from 1976 to 1992 . During this period, disk-drive performance improved at a stunning rate, yet no independent disk-drive company that existed in 1976 survived by 1995. Christensen expounded on the disruptive-innovation concept in a best-selling 1997 book The Innovator's Dilemma: When New Technologies Cause Great Firms to Fail. Top tech executives such as Amazon's Jeff Bezos and Apple's late co-founder Steve Jobs described the book as required reading for tech executives.

Christensen came under withering critique in 2014 from Jill Lepore, a Harvard history professor, in a New Yorker article, "The Disruption Machine: What the gospel of innovation gets wrong." Lepore called Christensen's sources "dubious" and his logic "questionable," and described disruptive innovation as "competitive strategy for an age seized by terror." A year later, Andrew A. King and Baljir Baatartogtokh argued, in an MIT Sloan Management Review article "How Useful Is the Theory of Disruptive Innovation?," that the idea had little predictive power. Other scholars have come to Christensen's defense.

But the disruptive innovation genie is out of the bottle and no scholarly de- bate will put it back there. Whether or not it has predictive power, it is a powerful story that explains the rise and fall of tech empires. By now it is deeply embedded in the psyche of Silicon Valley, and the phrase "to disrupt" has become a mantra of Silicon Valley business plans. Because people believe the disruptive innovation story, it shapes their behavior.

The disruption ideology has further mutated into what used to be, until 2014, Facebook's motto, "Move fast and break things. Unless you are breaking stuff, you are not moving fast enough." A company that epitomizes this approach is Uber. Its business model —of creating a platform to connect drivers and passengers - was absolutely brilliant. The transportation service Uber provided was vastly superior to that offered by taxi cabs, which led to its immense popularity and meteoric growth. The fact that this mode of transportation service violated traffic laws in many localities was ignored as a mere technicality. It is no wonder Uber was described by some as "a borderline criminal enterprise."

The break-things ideology was addressed in a 2017 book by Jonathan Taplin Move Fast and Break Things: How Facebook, Google, and Amazon Cornered Culture and Undermined Democracy. Taplin's basic thesis is that Silicon Valley does increasingly resemble "some kind of nightmarish children's playground, populated by overgrown babies with no idea of the consequences of their actions." While the book is thinly argued, the clamor against Silicon Valley is getting louder by the day. In a recent viral article "The Tech Industry's Psychological War on Kids," ${ }^{\text {b }}$ child psychologist Richard Freed argues "... parents have no idea that lurking behind their kids'

a https://bit.ly/2mPLnkC

b https://bit.ly/2tK9iID screens and phones are a multitude of psychologists, neuroscientists, and social-science experts who use their knowledge of psychological vulnerabilities to devise products that capture kids' attention for the sake of industry profit." Indeed, interviews with several tech executives revealed they raised their kids tech-free, which should have been a red flag to the public!

Christensen offered the paradigm of "disruptive technology" as an explanation of a business phenomenon. The description has morphed into a prescription, and disruption has morphed into "breaking things." But in the quest for rapid get-ahead-stayahead execution, entrepreneurs often forget to think about the broader context for their services or products, and the human and social setting that will be impacted by their entry. Technology is now one of the main forces driving society. Breaking things therefore means technology can have profound adverse societal consequences. Given recent political developments around the world, Taplin's assertion that technology undermined democracy does not sound too batty. It is this cavalier attitude about breaking things that led Wall Street Journal columnist Peggy Noonan to describe Silicon Valley executives as "moral Martians."

We should celebrate the amazing progress of technology over the past 70 years. Our profession has been leading this profound change. We are in the driver's seat. It is incumbent on us to drive very carefully!

Follow me on Facebook, Google+, and Twitter.

Moshe Y. Vardi (vardi@cs.rice.edu) is the Karen Ostrum George Distinguished Service Professor in Computational Engineering and Director of the Ken Kennedy Institute for Information Technology at Rice University, Houston, TX, USA. $\mathrm{He}$ is the former Editor-in-Chief of Communications.

Copyright held by author 